\title{
Induction of Cyclin A Gene Expression by Homocysteine in Vascular Smooth Muscle Cells
}

\author{
Jer-Chia Tsai, ${ }^{\star}$ Hong Wang, ${ }^{\star}$ Mark A. Perrella, ${ }^{\star \$ \|}$ Masao Yoshizumi, ${ }^{\star \S}$ Nicholas E. S. Sibinga, ${ }^{\star \S \uparrow}$ Larissa C. Tan, ${ }^{\star}$ \\ Edgar Haber, ${ }^{\star \S \uparrow}$ Ted Hung-Tse Chang, ${ }^{\ddagger}$ Robert Schlegel, ${ }^{\ddagger}$ and Mu-En Lee ${ }^{\star \S \uparrow}$ \\ *Cardiovascular Biology Laboratory and ${ }^{\ddagger}$ Department of Molecular and Cellular Toxicology, Harvard School of Public Health; \\ ${ }^{\S}$ Department of Medicine, Harvard Medical School; and "Pulmonary and "Cardiovascular Divisions, Brigham and Women’s Hospital, \\ Boston, Massachusetts 02115
}

\begin{abstract}
Homocysteine is an important and independent risk factor for arteriosclerosis. We showed previously that homocysteine stimulates vascular smooth muscle cell proliferation, a hallmark of arteriosclerosis. We show here that homocysteine and serum increased DNA synthesis synergistically in both human and rat aortic smooth muscle cells (RASMCs). Treatment of quiescent RASMCs with $1 \mathrm{mM}$ homocysteine or $2 \%$ calf serum for $36 \mathrm{~h}$ increased cyclin A mRNA levels by 8 - and 14-fold, respectively, whereas homocysteine plus serum increased cyclin A mRNA levels by 40-fold, indicating a synergistic induction of cyclin A mRNA. Homocysteine did not increase the half-life of cyclin A mRNA (2.9 h), but it did increase the transcriptional rate of the cyclin $\mathrm{A}$ gene in nuclear run-on experiments. The positive effect of homocysteine on cyclin A gene transcription was confirmed by our finding that homocysteine increased cyclin A promoter activity and ATF-binding protein levels in RASMCs. Finally, $1 \mathrm{mM}$ homocysteine increased cyclin A protein levels and cyclin A-associated kinase activity by threefold. This homocysteine-induced expression of cyclin A may accelerate progression of arteriosclerotic lesions by promoting proliferation of vascular smooth muscle cells. (J. Clin. Invest. 1996. 97:146-153.) Key words: atherosclerosis • transcription - gene regulation - cell cycle - myocardial infarction
\end{abstract}

\section{Introduction}

Arteriosclerosis and its complications such as heart attack and stroke are the major causes of death in developed countries (1). Despite considerable advances in our understanding of the causes of arteriosclerosis, the established risk factors do not fully explain its occurrence (2). Recently, elevated levels of homocysteine - an intermediate metabolite of methionine-have been identified as an important and independent risk factor

J.-C. Tsai and H. Wang contributed equally to this work.

Address correspondence to Dr. Mu-En Lee, Cardiovascular Biology Laboratory, Building 2, Harvard School of Public Health, 677 Huntington Avenue, Boston, MA 02115. Phone: 617-432-4994; FAX: 617-432-0031. J.-C. Tsai's present address is Kaohsiung Medical College, 100 Shih-Chuan First Road, Kaohsiung, Taiwan.

Received for publication 22 June 1995 and accepted in revised form 28 September 1995.

J. Clin. Invest.

(C) The American Society for Clinical Investigation, Inc.

0021-9738/96/01/0146/08 \$2.00

Volume 97, January 1996, 146-153 for arteriosclerosis (3-5). Hyperhomocysteinemia can be caused by deficiency in enzymes such as cystathionine $\beta$-synthase, vitamin deficiencies, drugs, or other, as yet undetermined, causes. Homocysteine levels have been found to be elevated in $20-30 \%$ of patients with premature arteriosclerosis (6-9). Moreover, a recent, large, prospective trial (the Physicians' Health Study) has defined elevated plasma homocysteine levels as an independent risk factor for myocardial infarction and stroke (10). In fact, $21 \%$ of the general population in the Framingham study had homocysteine levels that would increase their risk of heart attack by 3.4-fold (11). This percentage makes hyperhomocysteinemia a very common risk factor $(2,12)$. Yet the mechanisms by which hyperhomocysteinemia induces arteriosclerosis remain only partially understood (13-16).

Proliferation of vascular smooth muscle cells is one of the most prominent features of arteriosclerosis $(1,17)$. We have shown that homocysteine increases DNA synthesis in vascular smooth muscle cells while decreasing DNA synthesis in vascular endothelial cells (18). This stimulating effect of homocysteine on vascular smooth muscle cell proliferation represents a mechanism to explain homocysteine-induced arteriosclerosis. Homocysteine also increases steady state cyclin A mRNA levels and proliferation in quiescent rat aortic smooth muscle cells (RASMCs). ${ }^{1}$ However, despite the importance of cyclin A in G1/S transit and in the S and G/M phases of the cell cycle (1923 ), little is known about the regulation of this gene's expression, particularly by homocysteine.

In this report we show that homocysteine and serum increased DNA synthesis and cyclin A mRNA levels synergistically in both RASMCs and human aortic smooth muscle cells (HASMCs). Homocysteine increased the transcriptional rate of the cyclin A gene but did not affect the half-life of cyclin A mRNA. Moreover, homocysteine increased cyclin A promoter activity and ATF-binding protein levels in RASMCs. Finally, homocysteine increased both the abundance of the cyclin A protein and the activity of cyclin A-associated kinase.

\section{Methods}

Cell culture. RASMCs were harvested from male Sprague-Dawley rats (200-250 grams) by enzymatic dissociation according to the method of Gunther et al. (24) with modification $(18,25)$. HASMCs were purchased from Clonetics Corp. (San Diego, CA). Both RASMCs and HASMCs were cultured in DME (JRH Biosciences,

1. Abbreviations used in this paper: CAT, chloramphenicol acetyltransferase; CREB, cyclic AMP-responsive element-binding protein; HASMCs, human aortic smooth muscle cells; RASMCs, rat aortic smooth muscle cells; TBST, $20 \mathrm{mM}$ Tris (pH 7.5)/300 mM NaCl/0.3\% Tween 20 . 
Lenexa, KS) and supplemented with 10\% FCS (Hyclone Laboratories, Logan, UT), penicillin (100 U/ml), streptomycin $(100 \mu \mathrm{g} / \mathrm{ml})$, and $25 \mathrm{mM}$ Hepes (pH 7.4) (Sigma Chemical Co., St. Louis, MO). RASMCs and HASMCs were passaged every 4-7 d, and experiments were performed on cells three to eight passages from primary culture. After the cells had grown to $80 \%$ confluence, they were placed in quiescence medium ( $0.4 \%$ calf serum, Hyclone Laboratories) for $72 \mathrm{~h}$ before the experiments.

$\left[{ }^{3} H\right]$ Thymidine incorporation. RASMCs or HASMCs in 24-well plates were made quiescent by incubation in DME containing $0.4 \%$ calf serum for $72 \mathrm{~h} \mathrm{(18)}$ before addition of DL-homocysteine (Sigma Chemical Co.). Cells were labeled with $\left[\right.$ methyl $\left.-{ }^{3} \mathrm{H}\right]$ thymidine (DuPont-New England Nuclear, Boston, MA) at $1 \mu \mathrm{Ci} / \mathrm{ml}$ during the last $2 \mathrm{~h}$ of homocysteine treatment. After the cells had been labeled, they were washed with Dulbecco's PBS, fixed in cold $10 \%$ trichloroacetic acid, and washed with $95 \%$ ethanol. Incorporated $\left[{ }^{3} \mathrm{H}\right]$ thymidine was extracted in $0.2 \mathrm{~N} \mathrm{NaOH}$ and measured in a liquid scintillation counter. Values were expressed as the mean \pm SEM from four wells. Statistical analysis was performed by the Kruskal-Wallis test and significance was accepted at $P<0.05$.

RNA blot hybridization. Total RNA was obtained from cultured cells by guanidinium isothiocyanate extraction and centrifugation through cesium chloride (25). The RNA was fractionated on a $1.3 \%$ formaldehyde-agarose gel and transferred to nitrocellulose filters. The filters were hybridized at $68^{\circ} \mathrm{C}$ for $2 \mathrm{~h}$ with a random-primed, ${ }^{32} \mathrm{P}$-labeled rat cyclin A cDNA probe (18) in QuikHyb solution (Stratagene, La Jolla, CA). The hybridized filters were then washed in $30 \mathrm{mM}$ sodium chloride, $3 \mathrm{mM}$ sodium citrate, and $0.1 \%$ SDS solution at $55^{\circ} \mathrm{C}$ and autoradiographed with Kodak XAR film at $-80^{\circ} \mathrm{C}$ for $16-24 \mathrm{~h}$ or stored on phosphor screens for $6-8 \mathrm{~h}$. The filters were washed in a $50 \%$ formamide solution at $80^{\circ} \mathrm{C}$ and rehybridized with an oligonucleotide probe complementary to 18 s ribosomal RNA to correct for loading differences. The filters were then scanned and radioactivity was measured on a PhosphorImager running the ImageQuant software (Molecular Dynamics, Inc., Sunnyvale, CA).

Nuclear run-on analysis. Confluent RASMCs were either not stimulated (control) or stimulated with homocysteine for $36 \mathrm{~h}$. The cells were subsequently lysed and nuclei were isolated as described by Perrella et al. (25). Nuclear suspension $(200 \mu \mathrm{l})$ was incubated with $0.5 \mathrm{mM}$ each of CTP, ATP, and GTP and with $250 \mu \mathrm{Ci}$ of ${ }^{32} \mathrm{P}$-labeled UTP (3,000 Ci/mmol; DuPont-New England Nuclear). The samples were extracted with phenol/chloroform, precipitated, and resuspended at equal counts $/ \mathrm{min} / \mathrm{ml}$ in hybridization buffer $\left(3.4 \times 10^{6}\right.$ $\mathrm{cpm} / \mathrm{ml})$. Denatured probes $(1 \mu \mathrm{g})$ dot-blotted on nitrocellulose filters were hybridized at $40^{\circ} \mathrm{C}$ for $4 \mathrm{~d}$ in the presence of formamide. cDNAs for the cyclin A and $\beta$-actin genes were used as probes. The filters were then autoradiographed with Kodak XAR film for $3 \mathrm{~d}$.

Western blot analysis. Whole-cell lysates were prepared from cultured smooth muscle cells not stimulated (control) or stimulated with homocysteine for $34 \mathrm{~h}$ by boiling in lysis buffer containing $1 \%$ Triton X-100 and $40 \mathrm{mM}$ Hepes, $\mathrm{pH} 7.5$. Protein content in the smooth muscle cells was determined according to the method of Lowry as modified for the DC protein assay (Bio Rad Laboratories, Hercules, CA). Total protein $(30 \mu \mathrm{g})$ from homocysteine-stimulated cells and control cells was fractionated by $10 \%$ SDS-PAGE and transferred to a polyvinylidene difluoride membrane (Immobilon-P membrane; Millipore Corp., Bedford, MA). Probing and washing procedures were as described (26). Briefly, the membranes were blocked for $1 \mathrm{~h}$ in $20 \mathrm{mM}$ Tris ( $\mathrm{pH} 7.5) / 300 \mathrm{mM} \mathrm{NaCl} / 0.3 \%$ Tween 20 (TBST) containing 5\% Carnation nonfat dry milk and incubated overnight at $4^{\circ} \mathrm{C}$ in a 1:1,000 dilution of a rabbit polyclonal anti-human cyclin A antiserum (27) in the same blocking solution. The membranes were washed three times with TBST, incubated at room temperature with $0.5 \mu \mathrm{Ci} / \mathrm{ml}^{125}$ I-labeled protein A (ICN, Irvine, CA) in TBST, and washed four times in TBST before detection by indirect autoradiography with Kodak X-OMAT film and an intensifying screen. Bands were quantified in a PhosphorImager.

Immunoprecipitation and H1 kinase assays. RASMCs were har- vested for H1 kinase assay by treating the monolayer with trypsin $34 \mathrm{~h}$ after the addition of homocysteine. The $\mathrm{H} 1$ kinase assay was performed essentially as described (27). Briefly, cells were lysed and 50 $\mu \mathrm{g}$ of protein from each extract was immunoprecipitated with a 1:100 dilution of a polyclonal cyclin A antibody at $4^{\circ} \mathrm{C}$ for $1 \mathrm{~h}$, followed by a 1-h incubation in $20 \mathrm{mg} / \mathrm{ml}$ protein A-Sepharose beads (Pharmacia LKB Biotechnology, Inc., Piscataway, NJ) at $4^{\circ} \mathrm{C}$. Histone $\mathrm{H} 1$ kinase activity was determined by incubating the beads in $40 \mu \mathrm{l}$ of kinase buffer containing $\left[\gamma^{-}{ }^{32} \mathrm{P}\right]$ ATP $(6,000 \mathrm{cpm} / \mathrm{pmol} ; 100 \mathrm{mM})$ and histone $\mathrm{H} 1$ (Sigma Chemical Co.; $0.5 \mathrm{mg} / \mathrm{ml}$ ) for $20 \mathrm{~min}$ at $30^{\circ} \mathrm{C}$. Histone $\mathrm{H} 1$ kinase activity was detected by autoradiography and phosphorimaging after electrophoresis on $12 \%$ SDS-PAGE gels.

Transfection and luciferase assays. Construction of luciferase reporter plasmids $-266 /+205$ and $-133 /+205$ containing 266 and 133 bp of the human cyclin A $5^{\prime}$ flanking sequence has been described (28). The ATF consensus sequence TGACGTCA in plasmid -133/ +205 was mutated to TGCCCCCA to make plasmid $\mathrm{mt}-133 /+205$. RASMCs were transfected with $5 \mu \mathrm{g}$ of luciferase construct $-266 /$ $+205,-133 /+205$, and $\mathrm{mt}-133 /+205$ by the DEAE-dextran method followed by a 1-min DMSO shock $(29,30)$. To correct for variability in transfection efficiency, we cotransfected $5 \mu \mathrm{g}$ of pCAT-control (containing the potent SV40 enhancer and promoter driving the structural gene coding for chloramphenicol acetyltransferase [CAT]) in all experiments. The luciferase and CAT assays were performed as described $(28,29)$, and the ratio of luciferase activity to CAT activity in each sample served as a measure of normalized luciferase activity. Each construct was transfected at least three times, and each transfection was done in triplicate. The luciferase activity of each cyclin A plasmid treated with homocysteine was divided by that of the same plasmid treated without homocysteine. The difference of the ratio (mean \pm SEM, treated versus untreated) was presented as a percent increase induced by homocysteine. Comparisons were made by applying a factorial ANOVA followed by Fisher's least significant difference test. Statistical significance was accepted at $P<0.05$.

Gel mobility shift assay. Probes were made from double-stranded oligonucleotides synthesized according to the sequence of the cyclin A ATF site (bp -84 to -63 , 5'TGAATGACGTCAAGGCCGCGAG $3^{\prime}$ ). The probes were radiolabeled as described (28). A typical binding reaction mixture contained DNA probe at 20,000 cpm, $1 \mu \mathrm{g}$ of poly(dI-dC)•poly(dI-dC), $25 \mathrm{mM}$ Hepes ( $\mathrm{pH} 7.9), 40 \mathrm{mM} \mathrm{KCl}, 3$ $\mathrm{mM} \mathrm{MgCl} 2,0.1 \mathrm{mM}$ EDTA, $1 \mathrm{mM}$ dithiothreitol, $10 \%$ glycerol, and 3 $\mu \mathrm{g}$ of nuclear extract in a final volume of $25 \mu \mathrm{l}$. The reaction mixture was incubated at room temperature for $20 \mathrm{~min}$ and analyzed by $5 \%$ native PAGE in a $0.25 \times \mathrm{TBE}(22 \mathrm{mM}$ Tris $/ 22 \mathrm{mM}$ boric acid $/ 0.5 \mathrm{mM}$ EDTA). To determine the specificity of the DNA protein complexes, we performed competition assays with an unlabeled double-stranded oligonucleotide encoding the wild-type ATF-1 sequence or the mutated ATF-1 sequence. To characterize specific DNA-binding proteins, we incubated nuclear extracts with various antibodies for $12 \mathrm{~h}$ at $4^{\circ} \mathrm{C}$ before the addition of probe. The polyclonal antibodies were raised against human ATF-1, ATF-2, Jun, and cyclic AMP-responsive element-binding protein (CREB).

\section{Results}

Synergistic induction of DNA synthesis and cyclin $A m R N A$ in smooth muscle cells by homocysteine and serum. Quiescent RASMCs were treated with $1 \mathrm{mM}$ homocysteine, $2 \%$ serum, or $1 \mathrm{mM}$ homocysteine plus serum for $24 \mathrm{~h}$. $\left[{ }^{3} \mathrm{H}\right]$ Thymidine incorporation was then measured to assess the rate of DNA synthesis. Homocysteine alone and serum alone increased $\left[{ }^{3} \mathrm{H}\right]$ thymidine incorporation by 2.5 - and 10 -fold, respectively (Fig. $1 A$ ), whereas homocysteine plus serum increased $\left[{ }^{3} \mathrm{H}\right]$ thymidine incorporation by 25 -fold. This effect was not species specific because homocysteine and serum also synergistically increased DNA synthesis in HASMCs (Fig. $1 B$ ). To 
determine whether growth factors present in the serum, such as PDGF and homocysteine, could also increase DNA synthesis in a synergistic manner, we treated quiescent RASMCs with $1 \mathrm{mM}$ homocysteine, $20 \mathrm{ng} / \mathrm{ml}$ PDGF (the recombinant human $\mathrm{BB}$ isoform), or $1 \mathrm{mM}$ homocysteine plus $20 \mathrm{ng} / \mathrm{ml}$ PDGF. $\left[{ }^{3} \mathrm{H}\right]$ Thymidine incorporation in RASMCs increased by 1.9-, 3.9-, and 12-fold in response to $1 \mathrm{mM}$ homocysteine alone, $20 \mathrm{ng} / \mathrm{ml}$ PDGF alone, or $1 \mathrm{mM}$ homocysteine plus 20 $\mathrm{ng} / \mathrm{ml}$ PDGF, respectively (Fig. $1 C$ ). This synergistic effect was also observed for basic fibroblast growth factor. Thus, both serum and growth factors appear to act synergistically with homocysteine to increase DNA synthesis in RASMCs.

Because cyclin A has a critical role in DNA replication during the $S$ phase $(21,22,31)$, we tested whether homocysteine and serum increased cyclin A mRNA levels synergistically. RNA was harvested from quiescent RASMCs treated with 1 $\mathrm{mM}$ homocysteine, $2 \%$ serum, or $1 \mathrm{mM}$ homocysteine plus $2 \%$ serum for 24,36 , and $48 \mathrm{~h}$ and analyzed by Northern analysis with a rat cyclin A probe. Both homocysteine alone and serum alone caused a time-dependent increase in cyclin A mRNA levels in comparison with control. At $36 \mathrm{~h}$, homocysteine alone and serum alone increased cyclin A mRNA levels by 8- and 14-fold, respectively, whereas homocysteine plus serum synergistically increased cyclin A mRNA levels by 40-fold (Fig. 2 A). Similar synergistic effects were also apparent at 24 and $48 \mathrm{~h}$. We also treated RASMCs with various doses of homocysteine to determine whether this synergistic effect could be observed at lower concentrations. Consistent with our previous report that $0.1 \mathrm{mM}$ homocysteine increased thymidine uptake in RASMCs (18), homocysteine increased cyclin A mRNA levels in RASMCs at a concentration as low as $0.1 \mathrm{mM}$ (Fig. $2 \mathrm{~B}$ ). In addition, homocysteine increased cyclin A mRNA levels in a dose-dependent manner.

Homocysteine increased cyclin A $m R N A$ levels by increasing the gene's rate of transcription. To determine the precise mechanisms by which homocysteine increased steady state cyclin A mRNA levels, we first measured the cyclin A mRNA half-life in the presence or absence of homocysteine. In RASMCs grown in medium containing $2 \%$ serum, the estimated half-life of cyclin A mRNA was $2.9 \mathrm{~h}$, whereas in cells exposed to homocysteine the half-life was $\sim 2.4$ h (Fig. 3). Thus, the increase in cyclin A mRNA levels by homocysteine could not have been mediated by an increase in the stability of cyclin A mRNA.

We then treated RASMCs with $5 \mu \mathrm{g} / \mathrm{ml}$ actinomycin D (an inhibitor of transcription) during treatment with $1 \mathrm{mM}$ homocysteine to determine whether induction of cyclin A mRNA by homocysteine resulted from increased cyclin A transcription. Actinomycin D treatment blocked induction of cyclin A mRNA in RASMCs by homocysteine (Fig. 4 A), suggesting that mRNA induction occurred at the transcriptional level. These observations were confirmed by nuclear run-on analysis. Homocysteine increased the rate of cyclin A gene transcription but had no effect on that of $\beta$-actin gene transcription (Fig. 4 B). Together, these data indicate that the homocysteine-induced increases in cyclin A mRNA levels were caused by increases in the transcriptional rate of this gene.

Homocysteine increased cyclin A promoter activity and ATFbinding protein levels in RASMCs. Recently, we and others have cloned the human cyclin A gene and characterized the promoter $(28,32)$. The ATF site and its binding proteins (CREB and ATF-1) are important in regulating the activity of
A

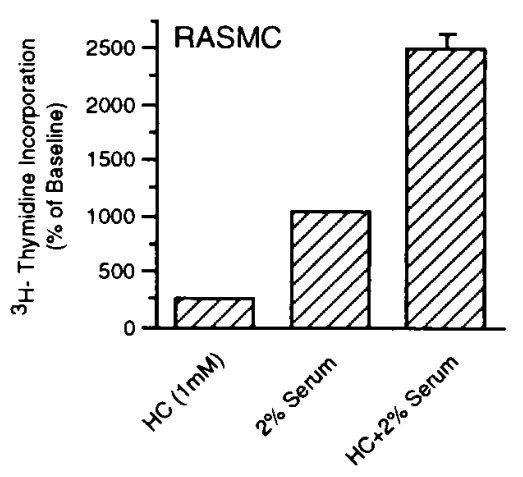

C

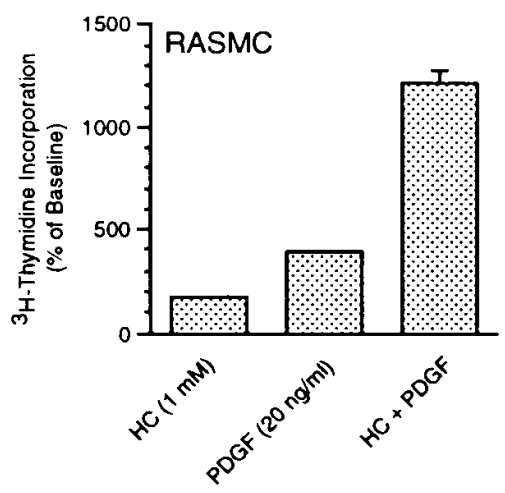

B

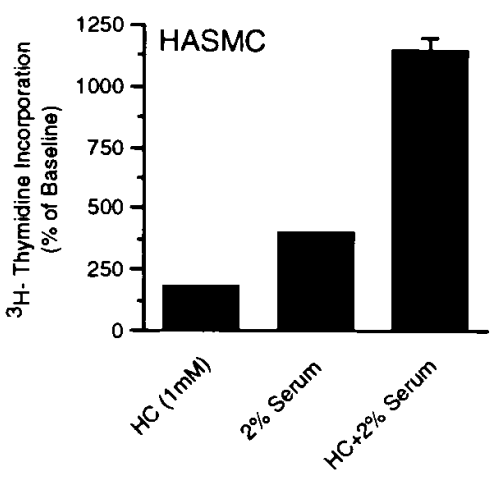

D

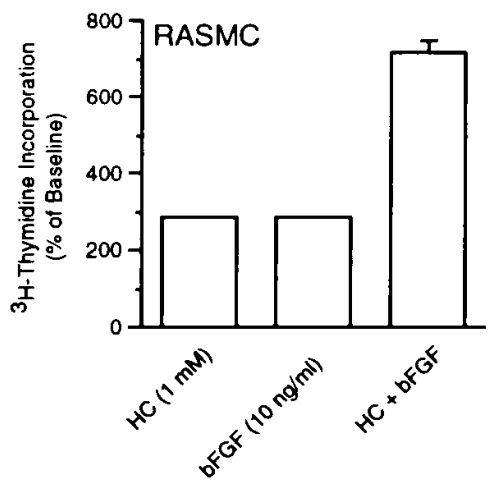

Figure 1. Synergistic induction of $\left[{ }^{3} \mathrm{H}\right]$ thymidine uptake by homocysteine and serum or PDGF. Subconfluent RASMCs $(A, C$, and $D)$ and HASMCs $(B)$ were made quiescent by incubation in medium containing $0.4 \%$ calf serum for $72 \mathrm{~h}$. Quiescent RASMCs $(A)$ and HASMCs $(B)$ were treated with $1 \mathrm{mM}$ homocysteine $(H C)$, $2 \%$ calf serum, or homocysteine plus $2 \%$ calf serum for $28 \mathrm{~h} .\left[{ }^{3} \mathrm{H}\right]$ Thymidine incorporation was measured during the last $2 \mathrm{~h}$. Values represent the mean \pm SEM from four wells. Baseline values were assigned a value of $100 \%$. In $C$ and $D, 20$ $\mathrm{ng} / \mathrm{ml}$ human recombinant PDGF-BB or $10 \mathrm{ng} /$ $\mathrm{ml}$ human recombinant basic fibroblast growth factor $(b F G F)$ was added instead of $2 \%$ serum. 



Figure 2. (A) Synergistic induction of cyclin A mRNA by homocysteine and serum. Subconfluent RASMCs were made quiescent as described for Fig. 1 and then not treated (Control) or treated with 1 $\mathrm{mM}$ homocysteine, $2 \%$ calf serum, or 1 $\mathrm{mM}$ homocysteine plus $2 \%$ calf serum for 24,36 , and $48 \mathrm{~h}$. Total cellular RNA was extracted and Northern analysis was performed using $10 \mu \mathrm{g}$ of RNA per lane. After electrophoresis, RNA was transferred to nitrocellulose filters, which were then hybridized to a ${ }^{32} \mathrm{P}$-labeled rat cyclin $\mathrm{A}$ probe and an 18s oligonucleotide probe. To correct for differences in RNA loading, the signal density for each RNA sample hybridized to the cyclin A probe was divided by that for each sample hybridized to the $18 \mathrm{~s}$ probe. The corrected value for each time point was then divided by that for its corresponding control time point. $(B)$ Dose-dependent induction of cyclin A mRNA by homocysteine. Quiescent RASMC were treated with $0.4 \%$ calf serum, $2 \%$ calf serum, or $2 \%$ calf serum plus various concentrations of homocysteine for $24 \mathrm{~h}$. Total RNA was extracted and analyzed as in $A$.

the cyclin A promoter $(28,33)$. To further elucidate the molecular mechanisms by which homocysteine increased cyclin A gene expression, we transfected into RASMCs luciferase reporter plasmids containing various lengths of the human cyclin A 5 ' flanking sequence. We chose plasmids $-266 /+205$ and $-133 /+205$ because we had shown previously that plasmid $-266 /+205$, which contains both the three proximal Sp1 motifs and the one ATF motif, directed full promoter activity (28). In addition, deletion of the three Sp1 motifs in plasmid -133/ +205 resulted in a $40 \%$ reduction in promoter activity (28). Despite high basal levels of luciferase activity (RASMCs were cultured in medium containing $2 \%$ fetal calf serum), homocysteine caused significant and similar increases in the luciferase activity of plasmids $-266 /+205$ and $-133 /+205$ (Fig. 5 A). In contrast, the effect of homocysteine on cyclin A promoter activity disappeared when the ATF site was mutated in plasmid 


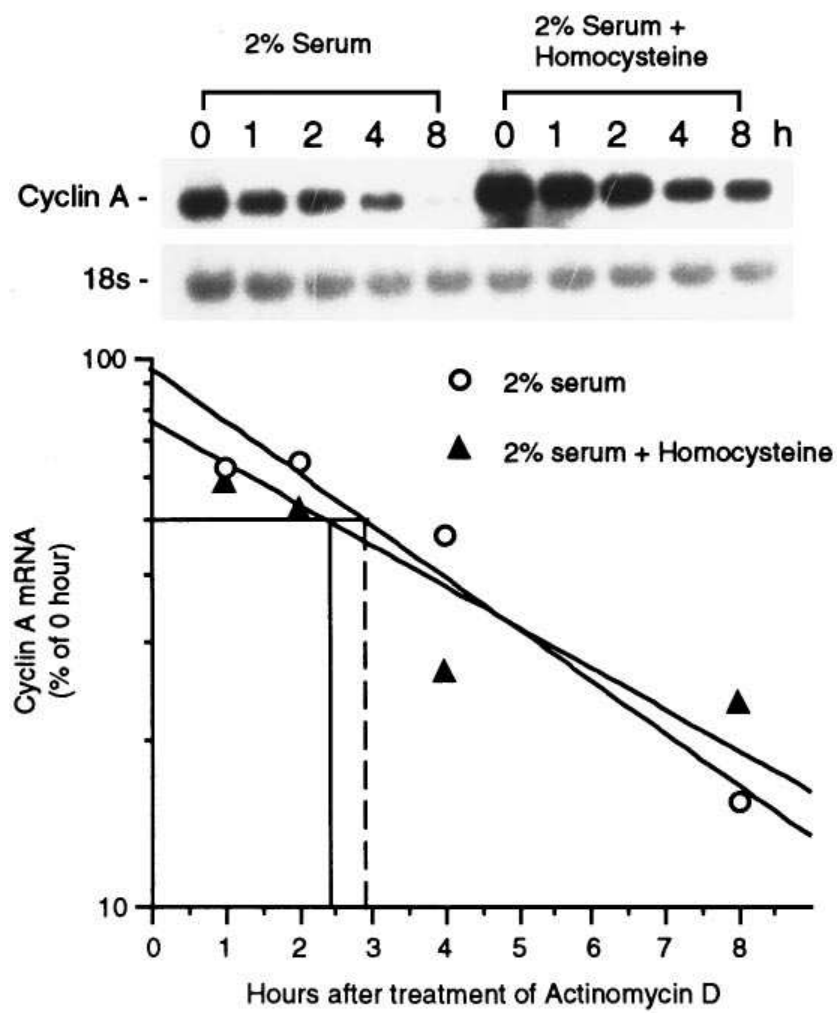

Figure 3. Effect of homocysteine on half-life of cyclin A mRNA. RASMCs were grown in medium containing either $2 \%$ calf serum or $2 \%$ calf serum plus $1 \mathrm{mM}$ homocysteine for $28 \mathrm{~h}$ followed by administration of actinomycin D $(5 \mu \mathrm{g} / \mathrm{ml})$. RNA was extracted at the indicated times after actinomycin D treatment. Northern blot analysis was performed with $10 \mu \mathrm{g}$ of total RNA per lane as described for Fig. 2. The corrected signal density was then plotted as a percentage of zero-hour value against time (in log scale).

mt $-133 /+205$ (Fig. 5 A), suggesting that the ATF site may mediate the positive effect of homocysteine on the cyclin A promoter.

To determine whether expression of ATF-binding proteins could be induced by homocysteine, we performed gel mobility shift analysis with a cyclin A ATF site probe. Incubation of the probe with nuclear extracts prepared rom RASMCs revealed specific DNA-protein complexes (collectively referred to as ATF-BP, Fig. 5 B) that were abolished by a 100 -fold molar excess of identical, nonradiolabeled DNA but not by a similar excess of nonidentical DNA (data not shown). These complexes were similar to previously reported complexes produced by nuclear extracts from vascular endothelial cells (28); however, the complexes from endothelial cells displayed three bands, whereas those from RASMCs displayed only two bands. Treatment of RASMCs with homocysteine resulted in marked and time-dependent increases in the ATF-BP complexes (Fig. 5 B).

To further identify the ATF-binding proteins present in the DNA-protein complexes, we performed gel mobility shift analysis in conjunction with antibodies. The ATF-BP complexes were competed away by the addition of ATF but not by the addition of mt ATF (Fig. 5 C). The anti-ATF-1 antibody abolished the lower ATF-BP band. The anti-CREB antibody completely abolished both bands and produced a supershifted

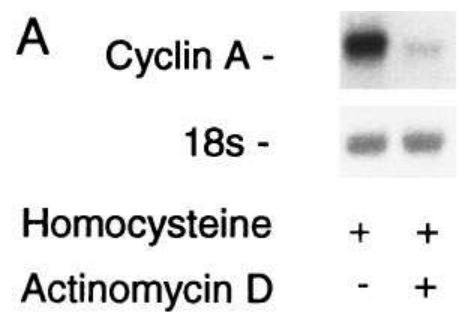

Figure 4. Effect of homocysteine on cyclin A gene transcription. $(A)$ Actinomycin D experiment. Subconfluent RASMCs were made quiescent by incubation in $0.4 \%$ calf serum for $72 \mathrm{~h}$ and then treated with $1 \mathrm{mM}$ homocysteine for $36 \mathrm{~h}$. Actinomycin D at $5 \mu \mathrm{g} / \mathrm{ml}$ was added $10 \mathrm{~h}$ before extraction of RNA. Total RNA $(10 \mu \mathrm{g})$ from each B

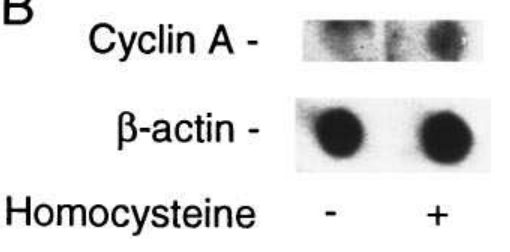
sample was subjected to Northern analysis with a rat cyclin A probe. (B) Nuclear runon experiment. Subconfluent RASMCs were placed in quiescence medium for $72 \mathrm{~h}$. The

smooth muscle cells were then stimulated with homocysteine for $34 \mathrm{~h}$ or treated with a vehicle for the same time period. Nuclei were isolated, and in vitro transcription was allowed to resume in the presence of $\left[\alpha-{ }^{32} \mathrm{P}\right] \mathrm{UTP}$. Equal amounts of ${ }^{32} \mathrm{P}$-labeled, in vitro transcribed RNA probes from each group were hybridized to $1 \mu \mathrm{g}$ of denatured cyclin A and $\beta$-actin cDNA that had been immobilized on nitrocellulose filters.

DNA-protein-antibody complex (Fig. 5 C). However, the anti-Jun and anti-ATF-2 antibodies did not affect the bands. These data indicate that ATF-1 and CREB are the specific binding proteins for the cyclin A ATF site in homocysteinetreated RASMCs.

Homocysteine increased cyclin A protein abundance and cyclin A-associated kinase activity in RASMCs. We performed Western blot analysis to determine whether the homocysteineinduced increases in cyclin A mRNA levels in RASMCs were accompanied by increases in the level of cyclin A protein. The antibody to cyclin A recognized a 58-kD band (Fig. $6 \mathrm{~A}$ ), as reported previously $(18,27)$. Quiescent RASMC cultures exposed for $34 \mathrm{~h}$ to homocysteine showed a threefold increase in cyclin A protein in comparison with controls. To determine whether cyclin A-associated kinase activity was also increased by homocysteine, cyclin A immunoprecipitates from control RASMCs and RASMCs that had been treated for $34 \mathrm{~h}$ with homocysteine were prepared and assayed for associated $\mathrm{H} 1 \mathrm{ki}-$ nase activity. Homocysteine increased cyclin A-associated kinase activity by more than threefold (Fig. $6 \mathrm{~B}$ ). Thus, homocysteine-induced increases in cyclin A mRNA levels were accompanied by increases in both the abundance of protein and the activity of cyclin A-associated kinase.

\section{Discussion}

Despite considerable epidemiological evidence identifying homocysteine as a risk factor for arteriosclerosis, the molecular mechanisms underlying homocysteine-induced arteriosclerosis have not been fully elucidated. Injury to vascular endothelial cells has been implicated in the pathogenesis of arteriosclerosis (1). The injured endothelium produces growth factors, which act on neighboring smooth muscle cells to promote their pro- 

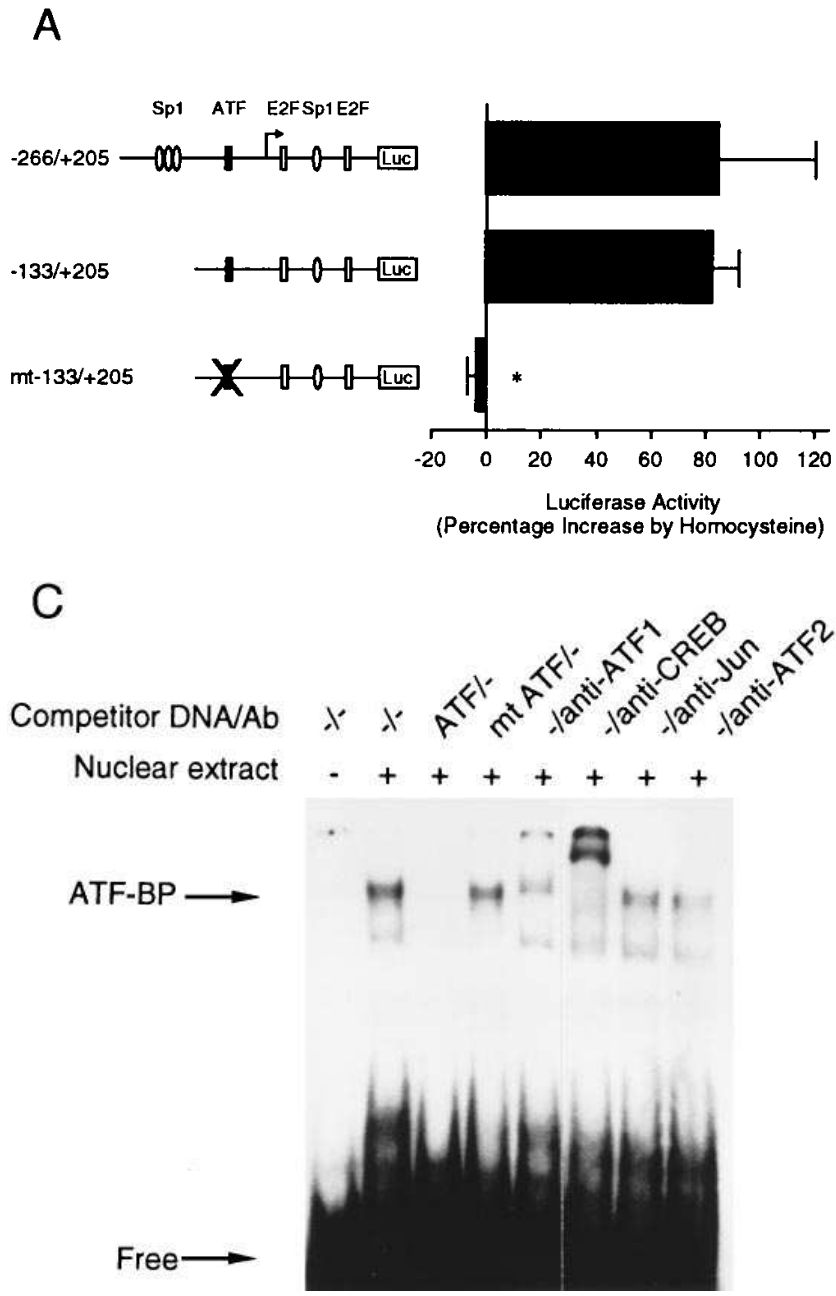

B



Figure 5. (A) Effect of homocysteine on cyclin A promoter activity. (Left) Plasmids containing various lengths of the $5^{\prime}$-flanking sequence of the cyclin A gene and the luciferase (Luc) reporter gene. The transcription start site and cis-acting elements are indicated by an arrow and boxes, respectively, as shown previously (28). Each plasmid $(5 \mu \mathrm{g})$ was transfected into RASMCs by the DEAE-Dextran method. $36 \mathrm{~h}$ after transfection, RASMCs grown in medium containing $2 \%$ fetal calf serum were then treated with or without homocysteine for $24 \mathrm{~h}$. For each construct, the plasmid pCAT-control was cotransfected to correct for differences in transfection efficiency. Luciferase activity and CAT activity were measured and relative luciferase activity units were assigned as described under Methods. (Right) Luciferase activity of each cyclin A plasmid treated with

homocysteine was divided by that of the same plasmid treated without homocysteine. The difference of the ratio (mean \pm SEM, treatment versus no treatment) is presented as a percent increase induced by homocysteine. ${ }^{*} P<0.05 \mathrm{mt}-133 /+205$ versus $-133 /+205 \mathrm{or}-266 /+205$. $(B)$ Effect of homocysteine on ATF-binding proteins. Gel mobility shift assays were performed with a double-stranded, ${ }^{32} \mathrm{P}$-labeled, 22 -bp oligonucleotide containing the ATF site of the cyclin A promoter and nuclear extracts from RASMCs treated with homocysteine for various periods. 36C represents the control at $36 \mathrm{~h}$. Incubation of the probe $(20,000 \mathrm{cpm})$ with nuclear extract from RASMCs resulted in DNA-protein complexes collectively referred to as ATF-BP. ATF-BP specificity was confirmed by competition studies with a 100 -fold excess of nonradiolabeled identical and nonidentical DNA (data not shown). (C) ATF-1 and CREB are the specific nuclear proteins that bind to the cyclin A ATF site in homocysteine-treated RASMC. Same assay as in B. Addition of nuclear extract from RASMCs treated with homocysteine for $12 \mathrm{~h}$ produced an ATF-BP that consisted of an upper and a lower band. The ATF-BP was competed away by the addition of ATF but not by the addition of mt ATF. To determine the specific components of the ATF-BP, we preincubated nuclear extracts with anti-ATF-1, -ATF-2, -Jun, and -CREB antibodies. The anti-ATF-1 antibody erased the lower band in ATF-BP. The anti-CREB antibody completely supershifted both bands. However, the anti-Jun and anti-ATF-2 antibodies did not affect the bands.

liferation. Thus, previous studies on homocysteine-induced atherosclerosis and thrombosis have focused on the effect of homocysteine on endothelial cells (13-16). Recently, we have shown that homocysteine increases DNA synthesis in RASMCs (18), suggesting that homocysteine may directly promote smooth muscle cell proliferation. In this report, we show that homocysteine also increases thymidine uptake in HASMCs (Fig. $1 B$ ). Furthermore, homocysteine and PDGF and fibroblast growth factor increase DNA synthesis in RASMCs synergistically (Fig. $1 C$ ). Because growth factors such as PDGF have been identified in arteriosclerotic lesions (1), homocysteine may also enhance the effect of growth factors or cytokines present in arteriosclerotic lesions to promote smooth muscle cell growth.
We have also tested the effects of methionine, cysteine, and glutathione on thymidine uptake in RASMCs over the same range of concentrations as studied for homocysteine. We found that cysteine and glutathione, but not methionine, caused similar increases in thymidine uptake in RASMCs (data not shown). This would indicate that the mitogenic effect of homocysteine is mediated mainly through its free sulfhydryl group.

As a first step toward elucidating the signal pathways of homocysteine-induced smooth muscle cell proliferation, we determined the effect of homocysteine on cyclin A gene expression. Cyclin A was chosen because it is required in more than one phase of the cell cycle. Cyclin A associates with two cyclin- 


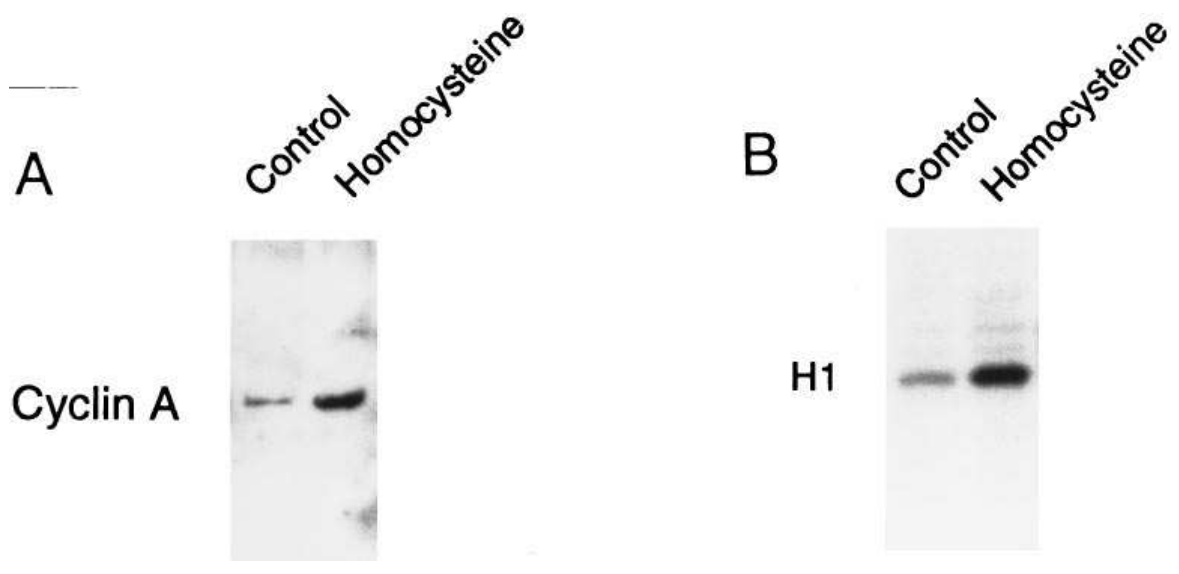

Figure 6. Effect of homocysteine on cyclin A protein and cyclin $\mathrm{A}$-associated kinase activity. ( $A$ ) Cyclin A protein. Subconfluent RASMCs were made quiescent for $72 \mathrm{~h}$ followed by treatment with or without $1 \mathrm{mM}$ homocysteine for $34 \mathrm{~h}$. Cell extracts were prepared from control and homocysteine-treated RASMCs. The protein concentration of the cell extract was measured and $30 \mu \mathrm{g}$ of protein from each sample was analyzed by Western blotting with a rabbit anti-human cyclin A polyclonal antibody. (B) Cyclin A-associated (H1) kinase activity. Subconfluent RASMCs were made quiescent by incubation in $0.4 \%$ serum for $72 \mathrm{~h}$ followed by treatment with or without $1 \mathrm{mM}$ homocysteine for $34 \mathrm{~h}$. Whole cell extracts were prepared and $50 \mu \mathrm{g}$ of protein was immunoprecipitated with a rabbit anti-human cyclin A polyclonal antibody. Cyclin A-associated kinase activity was assayed as described in Methods.

dependent kinases: cdk2 in the $\mathrm{S}$ phase of the cell cycle and $\mathrm{Cdc} 2$ in the G2/M phase. These associations are required for both DNA replication and mitosis $(21,22,31,34,35)$. Cyclin A can also affect G1/S transit, as overexpression of cyclin A but not other cyclins overcomes the G1/S block induced by loss of cell adhesion $(36,37)$.

We show here that homocysteine increases cyclin A mRNA levels, an effect markedly amplified by serum (Fig. 2). The induction of cyclin A mRNA by homocysteine occurs at the transcriptional level (Fig. 4) and homocysteine has no effect on the stability of cyclin A mRNA (Fig. 3). Furthermore, homocysteine-induced increases in cyclin A mRNA levels are associated with increases in cyclin A protein (Fig. $6 A$ ) and cyclin A-associated kinase activity (Fig. $6 B$ ). Thus, homocysteine-induced cyclin A gene expression may have an important role in vascular smooth muscle cell proliferation, a prominent feature of arteriosclerosis (1).

We and others have cloned the human cyclin A promoter and characterized several regulatory elements and cognate DNA-binding proteins important for cyclin A gene transcription $(28,32)$. The ATF site and its cognate DNA binding proteins (ATF-1 and CREB) are critical in mediating high-level cyclin A gene expression in vascular endothelial cells (28). The observations we report here indicate that homocysteine may also increase the rate of cyclin A gene transcription in RASMC through the same ATF site. Future work aimed at elucidating how homocysteine increases the level of ATFbinding proteins may provide important insights into the signal pathways of homocysteine-induced vascular smooth muscle cell proliferation.

\section{Acknowledgments}

We thank B. Ith for technical assistance and T. J. McVarish and R. L. Guerra for editorial assistance.

This work was supported by a grant from the Bristol-Myers Squibb Pharmaceutical Research Institute. Dr. Tsai was supported by a grant from the National Council of Science, Republic of China (NSC-85-2331-B037-018). Dr. Lee was supported by a grant from the National Institutes of Health (GM 53249), a Clinician Scientist Award, and a Grant-in-Aid from the American Heart Association, with funds contributed in part by the American Heart Association,
Massachusetts Affiliate. Dr. Schlegel was supported by grants from the National Institutes of Health (CA49749) and the Human Frontier Science Program.

\section{References}

1. Ross, R. 1993. The pathogenesis of atherosclerosis: a perspective for the 1990s. Nature (Lond.). 362:801-809.

2. Stampfer, M. J., and M. R. Malinow. 1995. Can lowering homocysteine levels reduce cardiovascular risk? N. Engl. J. Med. 332:328-329.

3. Malinow, M. R. 1990. Hyperhomocyst(e)inemia. A common and easily reversible risk factor for occlusive atherosclerosis. Circulation. 81:2004-2006.

4. Stampfer, M. J., and W. C. Willett. 1993. Homocysteine and marginal vitamin deficiency. The importance of adequate vitamin intake. J. Am. Med. Assoc. 270:2726-2727.

5. Ueland, P. M., and H. Refsum. 1993. Plasma homocysteine, a risk factor for vascular disease: plasma levels in health, disease, and drug therapy. J. Lab. Clin Med. 114:473-501.

6. Malinow, M. R., F. J. Nieto, M. Szklo, L. E. Chambless, and G. Bond. 1993. Carotid artery intimal-medial wall thickening and plasma homocyst(e)ine in asymptomatic adults. The Atherosclerosis Risk in Communities Study. Circulation. 87:1107-1113.

7. Clarke, R., L. Daly, K. Robinson, E. Naughten, S. Cahalane, B. Fowler, and I. Graham. 1991. Hyperhomocysteinemia: an independent risk factor for vascular disease. N. Engl. J. Med. 324:1149-1155.

8. Boers, G. H. J., A. G. H. Smals, F. J. M. Trijbels, B. Fowler, J. A. J. M. Bakkeren, H. C. Schoonderwaldt, W. J. Kleijer, and P. W. C. Koppenborg. 1985. Heterozygosity for homocystinuria in premature peripheral and cerebral occlusive arterial disease. N. Engl. J. Med. 313:709-715.

9. Coull, B. M., M. R. Malinow, N. Beamer, G. Sexton, F. Nordt, and P. de Garmo. 1990. Elevated plasma homocyst(e)ine concentration as a possible independent risk factor for stroke. Stroke. 21:572-576.

10. Stampfer, M. J., R. Malinow, W. C. Willett, L. M. Newcomer, B. Upson, D. Ullman, P. V. Tishler, and C. H. Hennekens. 1992. A prospective study of plasma homocyst(e)ine and risk of myocardial infarction in US physicians. $J$. Am. Med. Assoc. 268:877-881.

11. Selhub, J., P. F. Jacques, P. W. Wilson, D. Rush, and I. H. Rosenberg. 1993. Vitamin status and intake as primary determinants of homocysteinemia in an elderly population. J. Am. Med. Assoc. 270:2693-2698.

12. Selhub, J., P. F. Jacques, A. G. Bostom, R. B. D'Agostino, P. W. F. Wilson, A. J. Belanger, D. H. O'Leary, P. A. Wolf, E. J. Schaefer, and I. H. Rosenberg. 1995. Association between plasma homocysteine concentrations and extracranial carotid-artery stenosis. N. Engl. J. Med. 332:286-291.

13. Rodgers, G. M., and M. T. Conn. 1990. Homocysteine, an atherogenic stimulus, reduces protein $\mathrm{C}$ activation by arterial and venous endothelial cells. Blood. 75:895-901.

14. Lentz, S. R., and J. E. Sadler. 1993. Homocysteine inhibits von Willebrand factor processing and secretion by preventing transport from the endoplasmic reticulum. Blood. 81:683-689.

15. Hajjar, K. A. 1993. Homocysteine-induced modulation of tissue plasminogen activator binding to its endothelial cell membrane receptor. J. Clin. Invest. 91:2873-2879.

16. Stamler, J. S., J. A. Osborne, O. Jaraki, L. E. Rabbani, M. Mullins, D. 
Singel, and J. Loscalzo. 1993. Adverse vascular effects of homocysteine are modulated by endothelium-derived relaxing factor and related oxides of nitrogen. J. Clin. Invest. 91:308-318.

17. Schwartz, S. M., R. L. Heimark, and M. W. Majesky. 1990. Developmental mechanisms underlying pathology of arteries. Physiol. Rev. 70:11771209.

18. Tsai, J. C., M. A. Perrella, M. Yoshizumi, C. M. Hsieh, E. Haber, R. Schlegel, and M. E. Lee. 1994. Promotion of vascular smooth muscle cell growth by homocysteine: a link to atherosclerosis. Proc. Natl. Acad. Sci. USA. 91:6369-6373.

19. Dou, Q. P., A. H. Levin, S. Zhao, and A. B Pardee. 1993. Cyclin E and cyclin A as candidates for the restriction point protein. Cancer Res. 53:14931497.

20. Yoshizumi, M., W.-S. Lee, C.-M. Hsieh, J.-C. Tsai, J. Li, M. A. Perrella, C. Patterson, W. O. Endege, R. Schlegel, and M.-E. Lee. 1995. Disappearance of cyclin A correlates with permanent withdrawal of cardiomyocytes from the cell cycle in human and rat hearts. J. Clin. Invest. 95:2275-2280.

21. Pagano, M., R. Pepperkok, F. Verde, W. Ansorge, and G. Draetta. 1992. Cyclin A is required at two points in the human cell cycle. EMBO (Eur. Mol. Biol. Organ.) J. 11:961-971.

22. Girard, F. U. Strausfeld, A. Fernandez, and N. J. Lamb. 1991. Cyclin A is required for the onset of DNA replication in mammalian fibroblasts. Cell. 67: 1169-1179.

23. Sobczak, T. J., F. Harper, Y. Florentin, F. Zindy, C. Brechot, and E. Puvion. 1993. Localization of cyclin A at the sites of cellular DNA replication. Exp. Cell Res. 206:43-48.

24. Gunther, S., R. W. Alexander, W. J. Atkinson, and M. A. Gimbrone, Jr. 1982. Functional angiotensin II receptors in cultured vascular smooth muscle cells. J. Cell Biol. 92:289-298.

25. Perrella, M. A., M. Yoshizumi, Z. Fen, J.-C. Tsai, C.-M. Hsieh, S. Kourembanas, and M. E. Lee. 1994. Transforming growth factor-beta 1, but not dexamethasone, down-regulates nitric-oxide synthase mRNA after its induction by interleukin-1 beta in rat smooth muscle cells. J. Biol. Chem. 269:1459514600.

26. Oshima, J., K. E. Steinmann, J. Campisi, and R. Schlegel. 1993. Modu- lation of cell growth, p34 cdc2 and cyclin A levels by SV-40 large T antigen. Oncogene. 8:2987-2993.

27. Meikrantz, W., S. Gisselbrecht, S. W. Tam, and R. Schlegel. 1994. Activation of cyclin A-dependent protein kinases during apoptosis. Proc. Natl. Acad. Sci. USA. 91:3754-3758.

28. Yoshizumi, M., C.-M. Hsieh, F. Zhou, J-C. Tsai, C. Patterson, M. A. Perrella, and M.-E. Lee. 1995. The ATF site mediates downregulation of the cyclin A gene during contact inhibition in vascular endothelial cells. Mol. Cell. Biol. 15:3266-3272.

29. Lee, M.-E., K. D. Bloch, J. A. Clifford, and T. Quertermous. 1990. Functional analysis of the endothelin-1 gene promoter. Evidence for an endothelial cell-specific cis-acting sequence. J. Biol. Chem. 265:10446-10450.

30. Sambrook, J., E. F. Fritsch, and T. Maniatis. 1989. Molecular Cloning: A Laboratory Manual. Cold Spring Harbor Laboratory, Cold Spring Harbor, NY.

31. Sherr, C. J. 1994. G1 phase progression: cycling on cue. Cell. 79:551-555. 32. Henglein, B., X. Chenivesse, J. Wang, D. Eick, and C. Brechot. 1994. Structure and cell cycle-regulated transcription of the human cyclin A gene. Proc. Natl. Acad. Sci. USA. 91:5490-5494.

33. Desdouets, C., G. Matesic, C. A. Molina, N. S. Foulkes, P. SassoneCorsi, C. Brecho, and J. Sobczak-Thepot. 1995. Cell cycle regulation of cyclin A gene expression by the cyclin AMP-responsive transcription factors CREB and CREM. Mol. Cell. Biol. 15:3301-3309.

34. Cardoso, M. C., H. Leonhardt, and B. Nadal-Ginard. 1993. Reversal of terminal differentiation and control of DNA replication: cyclin A and Cdk2 specifically localize at subnuclear sites of DNA replication. Cell. 74:979-992.

35. Pines, J., and T. Hunter. 1991. Human cyclins A and B1 are differentially located in the cell and undergo cell cycle-dependent nuclear transport. $J$. Cell Biol. 115:1-17.

36. Barrett, J. F., B. C. Lewis, A. T. Hoang, R. J. J. Alvarez, and C. V. Dang. 1995. Cyclin A links c-Myc to adhesion-independent cell proliferation. $J$. Biol. Chem. 270:15923-15925.

37. Guadagno, T. M., M. Ohtsubo, J. M. Roberts, and R. K. Assoian. 1993. A link between cyclin A expression and adhesion-dependent cell cycle progression. Science (Wash. DC). 262:1572-1575. 